\title{
Local Wisdom Values in EFL Online Learning: Emerging Environtmental Issues
}

\author{
Nurul Puspita ${ }^{1}$, Umar Alfaruq A. Hasyim² \\ 1Pendidikan Bahasa Inggris, Fakultas Tarbiyah dan Keguruan, \\ UIN Raden Intan Lampung \\ ${ }^{2}$ Tadris Bahasa Inggris, Fakultas Tarbiyah, Institut Agama Islam \\ Ma'arif (IAIMNU) Metro
}

\begin{abstract}
Local wisdom values mean society awareness about their ability in recognizing the surrounding condition. In this context, the values refer to the Lampungnese custom in planting crop. Unfortunately, many EFL learners were not familiar with their surroundings. Furthermore, this research describes the used of environmental issue topic in learning Essay writing. The teaching and learning process was done by EFL students by using online platform. It was suggested during the pandemic situation. However, the aim of this research is describing EFL students' activities in emerging environmental topic toward their essay. This research was done on second semester of essay writing students. It was about 27 students. In conducting the teaching and learning process the lecturers choose any pictures that deal with the local culture of Lampungnese in planting crop as a topic. Then, the students would be more familiar with the values of the culture and elaborate the values in term of essay writing.
\end{abstract}

Keywords: Local Wisdom, Online Learning, Environmental Issues, Writing, Essay

\section{INTRODUCTION}

Emerging local wisdom in EFL class can be a way to raise students' awareness about local norms and values through teaching and learning process. In other words, learning language and incorporating local wisdom values should work simultaneously in order to reach the goal of learning. In addition, (Septy, 2017) added that local wisdom is the source of conventional value naturally grown up and derived from the social and natural environment that then become philosophical-deep thoughts in controlling and developing better socio-cultural system of a certain group of people. It can be said that the nature of local wisdom came from their daily activities in their own community. It is used as the basic of their life. 
Moreover, Local wisdom is related to the community's ability to understand the surrounding condition and the environment, which then is adapted to the existing situation. Local wisdom contributes to the way of living, knowledge and life strategies in the form of actions done by the local community to respond to various problems and meet their needs in life (Laili, 2017). It means that a society has to aware about their self capability in recognizing the situation among them. It is concerning to the habit and comprehension of life. They must also react any obstacles face in daily activities

In Indonesian context, the values of the local wisdom are spread around the country due to Indonesia has variety of social groups. This condition leads Indonesia rich of source local values that can used to build personality, identity and the character of the learners. Then, it is the duty of the teacher and the lecturer to emerge and manage the EFL writing materials with the values of the local wisdom to the learners. After doing this, it is expected learners use English as means of communication with the good character based on the values of the local wisdom.

In university level, this environmental issues can be implemented in EFL writing class, especially in academic writing. In this context, the students can drill their writing skill by practicing how to write an essay with environmental-related contents and the local community solve that issue. This activities not only hone the students' writing skills but also sharpen their critical thinking about local environment situation.

In general it can be assumed that writing is a thinking process to produce a written text. It is obtained by process of thinking to arrange the words into the sentences, and then the sentences are grouped together into the paragraphs. The result of the written text is reflection of the mental activity of the writer in understanding the context situation that faced by the researcher (Puspita \& Hasyim, 2019). 
Because of that, learning to write is not an easy task to do. Many students still make errors and mistakes and, then, they are fossilized (Nurul \& Umar Al Faruq, 2017). Their interest becomes less and less and students begin to create negative stimuli about learning to write. This condition drives the students to assume that writing is a very difficult task to do. The problem emerges as students are not familiar yet with the types of written discourse in English due to lack of exposure. Consequently, they are not able to or willing to think directly in English. They, then, tend to formulate their ideas in Indonesian language when they express ideas in writing. Afterward they try to translate them into English which is not an easy task and even dangerous.

In brief, writing is a process that occurs over a period of time, particularly if we take into account the sometimes extended periods of thinking that precede creating an initial draft. Furthermore, writing also defines as a mental activity of skilful decision-making, appropriate for the situation. It means that the writer is able to make decision as consideration to the purpose of writing, the objective of the readers in reading text, situation and condition during the process of writing done.

The context of learning writing here is learning an essay. In general essays writing fall along a continuum between those that ask you to describe a particular phenomenon, and those that ask to discuss, analyze, criticize and debate particular issues (Puspita, 2019). Furthermore, it deals with specific event or current trend among the society. The event and trend are portrayed the activities in a period of time. In addition, the readers may read the result of description. The description above is explained into some stages. For instance, outlining, drafting, revising or editing (Puspita \& Hasyim, 2021).

In elaborating the essay, the learner should notice to the part of essay. They are introductory paragraph, body paragraph, and concluding paragraph. The content of essay should be developed well based on the topic of the essay itself. The topic taken in this research was about the emerging of local wisdom values

Doi: $\underline{\text { https://doi.org/10.25217/jed.v1i01.1713 }}$ 
use by Lampungese. It was about the planting crop customs done by the society in Lampung Province. This activity is done in LMS of UIN Raden Intan Lampung (E-Learning).

Due to the pandemic situation faced by our society the teaching and learning process of writing was using online platform. Online learning is interesting English as a Foreign Language (EFL) educational resource, for it provides convenience and flexibility to students. It has been widely used to promote students in academic discourse for knowledge construction (Emaliana \& Rohmah, 2020). E-learning is identified as courses that are conveyed through web to some places other than the real classes where the educator is instructing in a non-virtual way and students can speak and interact with instructors or other students (Farrah \& al-Bakry, 2020).

On the other words, Environmental issues concern on the environment crisis and protections due to human activities. Furthermore, the environmental issues cover global warming, pollution, deforestation, etc. Deforestation is a main environmental issue happened in Indonesia. Data shows that 465,500 area of forest are on deforestation (PPID, 2020). In addition, in 2021 the deforestation remain lower that reach 115,460 hectars (aqil, 2021). In addition, Sumatra is the most affected by the deforestation, this deforestation happened in Sumatra contributes the global deforestation which reach 170 billion hectars (BBC News, 2015).

Thus, from the previous data it can be assumed that the deforestation become the main concern in Indonesia. Therefore, all elements concerning to that issue hand in hand solve the problems. It was clear that today the deforestation remain lower. In the other hand, the local society also hold important role in preventing the deforestation. Thus, it needs to be learned the local way of the local community in conserving the nature. The values underpinning the local way or local wisdom should be revealed in order to broaden the nature conservation in Indonesia. 
There are several prior studies which concern about this issue. For example, Study about internalizing the environmental issues in EFL context was also carried out by Nkwetisama (Nkwetisama, 2011). He concerned the study on environmental education towards an Eco-Applied Linguistic Awareness in Cameroon Context. Theresult of the study showed that the profession English language teaching can be used in promoting environmentally-friendly behaviours among citizens, more specifically by activating an eco-applied linguistic awareness among Cameroonian EFL/ESL teachers.

Nevertheless, this research is focus on the emerging of local wisdom value in form of local custom of environmental issue. The students are asked to create an essay which the content is about the planting of crop done by Lampung society. There are some technical terms on it like Behuma and Najuk. By implementing this topic it would increase learners' awareness toward their knowledge of local wisdom values. At last, the aim of this research is portraying the emerging of environmental topic.

\section{RESEARCH METHODOLOGY}

This study is a descriptive qualitative research with aiming at describing the implementation of emerging local environmental issues as a topic of essay writing. According Ary et al (2018) the qualitative inquirer deals with data that are in the form of words or pictures rather than numbers and statistics. The data collected are participant experiences; the qualitative research attempts to arrive at a rich description of the people, objects, events, places, conversations, and so on.

The subjects of this study are the 4th semester students of English Education Department in UIN Raden Intan Lampung which enroll essay writing class. The total number of the students are 27, with 4 male and 23 female. All students in essay writing class had been gotten basic writing class in their previous semester.

Doi: https://doi.org/10.25217/jed.v1i01.1713 
The data will be collected by using an instruments, it is observation. The observation is conducted to gain the data about how environmental issues are emerged in essay writing class. The observation will be conducted virtually by using tools of technology, such as zoom, whatsapp, and google form.

The data of the study will be analyzed by using descriptive analysis as follows:

1. Data reduction

The data collected from the instruments will then be selected which are suitable with the focus of the discussion. From the important points that the writers have selected, then the writers construct the main points and arrange them systematically in order to provide an overview of the result.

2. Data display

After reducing the data, the writer will analyze and describe the data qualitatively.

3. Conclusion/verification

After analyzing the data, the writer will draw a conclusion about the process of teaching and learning in academic writing which emerged the environmental issues and conclude the students perceptions about their writing class.

\section{RESULT AND DISCUSSION}

The implementation of local wisdom values in teaching writing is presented in the classroom. It was showed by emerging the topic of essay that deals with local environmental issue. For instance, it took about the Lampungnese customs in planting a corps. Before, doing the writing activity, the lecturer explain about the definition part of essay. Moreover, the lecturer also gave example of an essay. The lecturer also expalined how to elaborate a good essay taken from the topic.

Doi: $\underline{\text { https://doi.org/10.25217/jed.v1i01.1713 }}$ 
In addition, the students started the activity based on the following essay. It was the part of essay. This essay was presented in meeting 4, $3^{\text {rd }}$ March 2021. It was conducted in the fourth semester of English department faculty of Tarbiyah and Teacher Training UIN Raden Intan Lampung. The following was part of essay;



Figure 1. Part of Essay by Oshima

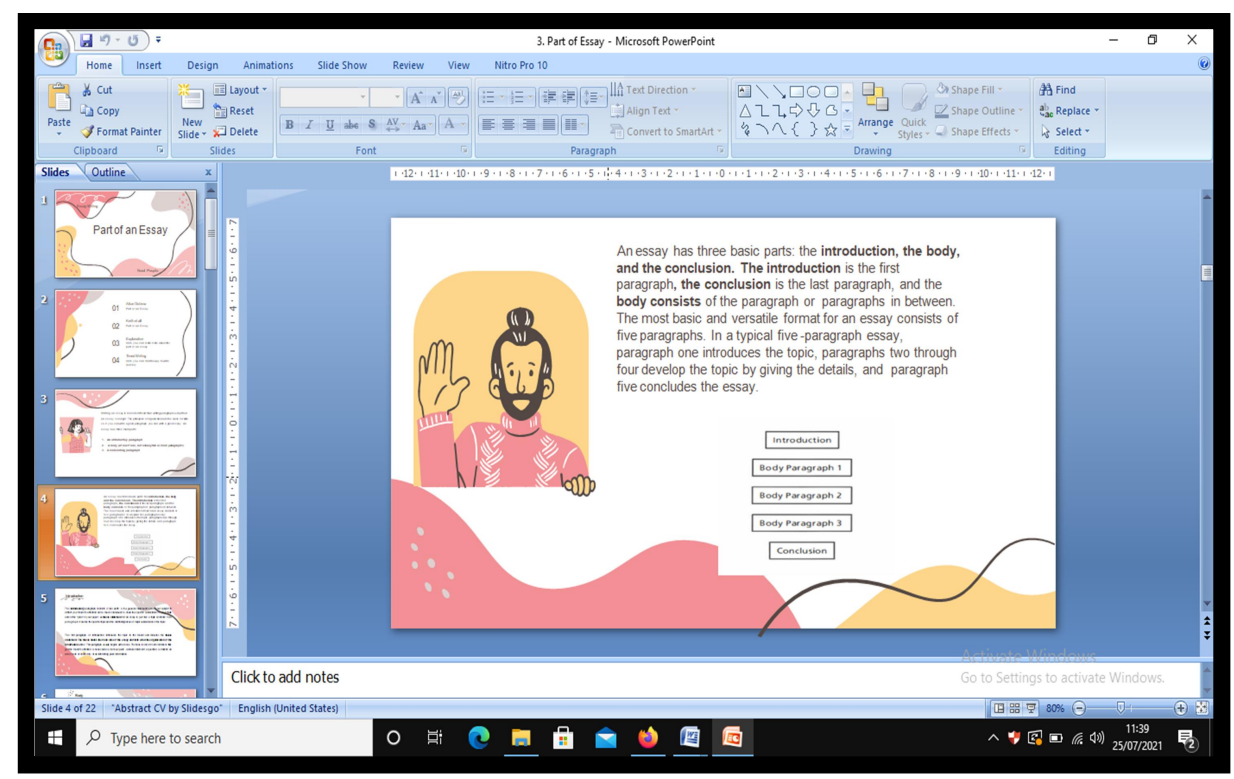

Figure 2. Part of Essay By Keith

Doi: https://doi.org/10.25217/jed.v1i01.1713 
The following is the teaching and learning process of essay writing by using local wisdom values topic. In this table presented the activities of the lecturer and the students during the process;

Table 1. Teaching \& Learning Process






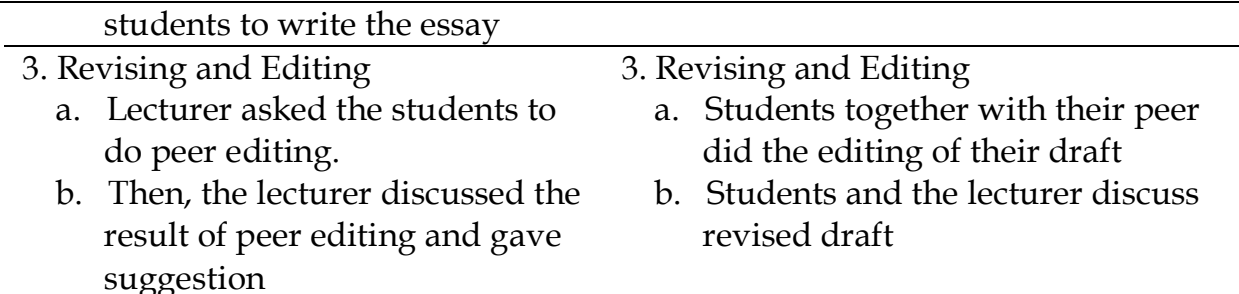

The process of writing is started in planning. After that, there are drafting and revising or editing. In planning stage the students looked for some information about the topic served by the lecturer. It deals about local tradition in planting corps. For instance, Nugal Tradition is a tradition of pepper planting usually done by West Lampung society. In this stage, the students were explained about the arrangement of part essay in detail. Furthermore, they tried to read some article related to the topic. It would make them easy in making outline then elaborating the ideas into essay. The next stage is drafting. The students made their own draft from introductory paragraph, body of paragraph, and concluding paragraph. Each of paragraphs should be elaborated well. The lecturer assisted the students in expressing every single idea into essay. They should notice some words that deal with Nugal Tradition. It was represented with some words like Ngelakar, Ngusi, lalang-lang bergurau. Those words are taken from Lampung vocabularies. In this context, they express some ideas in elaborating the essay. The first part is Introductory Paragraph; the students are guided to make the thesis statement. It includes main idea taken from the topic. The second part is Body Paragraph; the students should elaborate each topic sentence in the body by using supporting sentences. The third is concluding Paragraph; the students are asked to restate any ideas in the essay by using transition signal of conclusion. At last, the students were on revising or editing stage. The students did peer correction with their partner. It is done to get any suggestion for essay betterment. They used pointer or guideline in doing peer correction. 
Here is the result of students' essay with the topic Nugal;

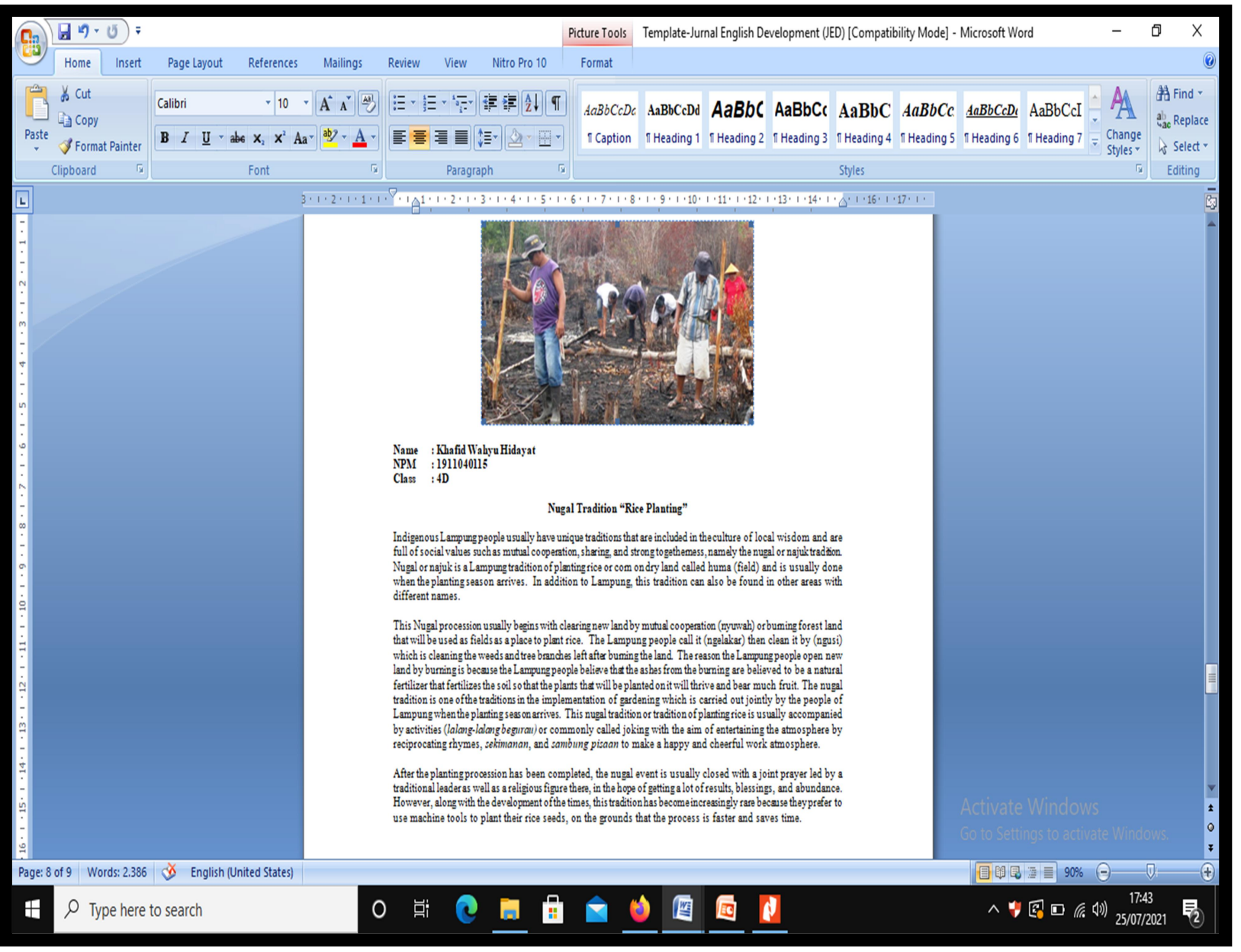

Figure 3. Students' Essay

\section{CONCLUSION}

Teaching and learning process is not always related to the use of language in performing oral and written discussion, but character building is also necessary. Furthermore, learners can find any knowledge easily from many sources. On the other words, it is difficult for them to learn about character building. Through the emerging of environmental issue in term of local tradition topic, the learner can build good character easily. Thus, this research told the process of teaching English as Foreign Language especially writing skill. The writing skill focused on making an essay. It was divided in to several steps namely; planning, drafting, revising and editing. Then, the 
part of essay is also divided into three. They are introductory paragraph, body paragraph, and concluding paragraph. The process of internalizing the local wisdom presented in those steps. Students were presented with the local culture of Lampung such as; Nugal and Behuma.

The lecturer also asked the students to read some articles to add their information in elaborating the ideas of the essay. They found some words that support in expressing their essay. The words are important information as well as the values provided in the local culture. After that students were guided to write an essay based on the local culture of Lampung. It is expected by understanding the local culture of Lampung, the values of the culture will be internalized in to habitual action of the students and create a good character. This character based local values will protect them from inappropriate target language culture being learned.

\section{REFERENCES}

aqil, I. (2021, March 6). Indonesia claims success for lowest deforestation rate in 5 years. The Jakarta Post. https://www.thejakartapost.com/news/2021/03/06/ministry-claims-success-for-lowestdeforestation-rate-in-5-years.html

Ary, D., Jacobs, L. C., Irvine, C. K. S., \& Walker, D. (2018). Introduction to research in education. Cengage Learning.

BBC News. (2015). Hutan Sumatera dan Kalimantan sumbang deforestasi global. BBC News Indonesia. https://www.bbc.com/indonesia/berita_indonesia/2015/04/150428_sains_hutan

Emaliana, I., \& Rohmah, K. (2020). Efl Students’ Speaking Achievement And Its Relationship With Epistemic Beliefs. IJET (Indonesian Journal of English Teaching), 9(2), 131-140.

Farrah, M., \& al-Bakry, G. H. (2020). Online learning for EFL students in Palestinian universities during corona pandemic: Advantages, challenges and solutions. Indonesian Journal of Learning and Instruction, 3(2).

Doi: $\underline{\text { https://doi.org/10.25217/jed.v1i01.1713 }}$ 
Laili, M. (2017). Fostering English Literacy Development In Writing Class Through Mind Mapping Integrated With Character Building and Local Wisdom.

Nkwetisama, C. M. (2011). EFL/ESL and Environmental Education: Towards an Eco-Applied Linguistic Awareness in Cameroon. World Journal of Education, 1(1), 110-118.

Nurul, P., \& Umar Al Faruq, A. H. (2017). Discourse Analysis on the Cohesion of Descriptive Writing Produced by Students of UIN RIL Lampung. Jurnal Iqra': Kajian Ilmu Pendidikan, 2(2), $347-$ 365.

PPID. (2020, April 22). Hutan dan Deforestasi Indonesia Tahun 2019. http://ppid.menlhk.go.id/berita/siaran-pers/5398/hutan-dan-deforestasi-indonesia-tahun-2019 Puspita, N. (2019). A Portfolio for Millennial Learners in Essay Writing Class. English Education: Jurnal Tadris Bahasa Inggris, 12(2), 87-99.

Puspita, N., \& Hasyim, U. A. A. (2019). Implementing Blended Learning to Promote Sustainable Teaching and Learning Process in Writing Class. English Education: Jurnal Tadris Bahasa Inggris, 12(1), 120-128.

Puspita, N., \& Hasyim, U. A. A. (2021). Book Club Discussion: An Extensive Reading Program in Writing Class. Attractive: Innovative Education Journal, 3(2), 113-123.

Septy, A. P. (2017). Technology Mediated literacy Education to local wisdom in English Language Teaching. 